\title{
The adoption of High Performance Work Practices in small businesses: the influence of markets, business characteristics and HR expertise
}

\begin{abstract}
$\underline{\text { Abstract }}$
This paper explores the extent to which the adoption of High Performance Work Practices (HPWPs) in UK small businesses with fewer than 50 employees is associated with the nature of the market in which the business operates, its business characteristics and its access to HR expertise. Drawing on data from the 2004 Workplace Employment Relations Survey, the analysis suggests that, where market-related factors are concerned, the uptake of HPWPs is higher in small businesses that require a highly-skilled workforce but is unrelated to either the degree of market competition or the presence of large dominant customers. In terms of access to HR expertise, the analysis finds greater use of HPWPs in small businesses that have contact with external sources of HR advice via membership of business advisory networks or Investors in People (IiP) recognition. However, uptake is unrelated to the presence of personnel/HR specialists. Overall, the findings suggest that rather than depicting employment practices in small businesses as the inevitable consequence of market circumstances, encouraging greater small business involvement with business advisory networks and IiP may have the potential to increase the adoption of HPWPs in the sector.
\end{abstract}

$\underline{\text { Introduction }}$

Considerable debate has emerged recently over the role that High Performance Work Practices (HPWPs) might play in enhancing small business performance. Despite concerns that the additional labour costs associated with using HPWPs may outweigh their productivity-enhancing benefits (Faems, Sels, de Winne and Maes 2005; Way 2002), HPWPs have been found in small businesses to raise labour productivity and reduce voluntary turnover (Deshpande and Golhar 1994; Faems et al.2005; Messersmith and Guthrie 2010; Sels et al. 2006; Way 2002), and to be associated with financial performance and profitability (Sels et al. 2006, p. 319; Wu, Hoque and Bacon 2011). It would appear, therefore, that the positive relationship identified between HPWPs and performance in firms more generally (for reviews of the HPWP-performance literature, see: Becker and Huselid 1998; Combs, Liu, Hall and Ketchen 2006) may exist within small businesses also. 
The existence of an HPWP-performance link in small businesses has also been acknowledged by both small business employers' associations and the British government (Federation of Small Businesses 2010; Small Business Service 2002, p. 4), and given this, a variety of policies have been introduced in Britain aimed at boosting the adoption of HPWPs within the sector. Examples include the Small Firms Initiative aimed at increasing the uptake of Investors in People (IiP) (Curran and Blackburn 2000, p.12), and the support services offered to small businesses through the Jobcentre Plus Small Business Recruitment Service, which provides professional and financial support and advice on recruitment, pre-employment training, on-thejob training, apprenticeships and work trials. The British government views support of this nature as particularly important given the role that small businesses play in generating employment and economic growth, with UK businesses employing fewer than 50 employees accounting for $99.2 \%$ of private sector enterprises, $46.2 \%$ of private sector employment and $34.9 \%$ of private sector turnover (in terms of the value of sales, work done and services rendered) (BIS 2011).

However, while HPWPs are not completely absent within small businesses (Bacon, Ackers, Storey and Coates 1996; Forth, Bewley and Bryson 2006), it is generally accepted that their uptake is somewhat limited (Dundon and Wilkinson 2003; Wilkinson 1999). There may, therefore, be considerable value in seeking to identify the factors that are associated with the adoption of HPWPs in small businesses. The aim of this paper is to draw on data from the 2004 Workplace Employment Relations Survey (WERS) (Department of Trade and Industry 2005) to explore the factors that are associated with the uptake of HPWPs in small businesses. Following the approach taken by the OECD (2005, p. 17), the European Commission (2003) and the U.S. 
Small Business Administration (2003), small businesses are defined in this paper as private sector businesses that have fewer than 50 employees.

What factors might influence the adoption of HPWPs in small businesses?

The extant literature suggests that the approach small businesses take to HRM (and hence the likelihood that they will introduce HPWPs) will be contingent on a range of factors. These arguably fall into three categories. The first concerns the nature of the market in which the business operates, the second concerns the characteristics of the business, and the third concerns the extent to which the business has access to HR expertise. The ensuing sections explore these three categories in turn.

\section{Market-related factors}

Four factors relating to the market in which small businesses operate might be expected to be related to the uptake of HPWPs: the competitiveness of the market; the presence of large/ dominant customers; the workforce skill-mix required by the business's product market strategy; and industry sector.

Turning to the first of these factors, small businesses are arguably particularly susceptible to market competition (Kinnie et al. 1999) given the difficulties they face in shifting into alternative markets in the face of severe competitive threats (Edelman, Brush and Manolova 2005; Storey 1994). In terms of the uptake of HPWPs, market competition has the potential to drive down prices and reduce the resources available for HR investments, thus lowering the likelihood that HPWPs will be adopted. However, market competition might also drive 
businesses to identify and adopt the most efficient practices, thus resulting in the introduction of HPWPs (Osterman 1994).

Second, large or dominant customers - a particular feature of the small business customer base (Forth et al. 2006, p.13) - have been found to be influential in encouraging their small business suppliers to adopt more sophisticated HRM approaches (Gales and Blackburn 1990; Hendry, Arthur and Jones 1995; Hunter, Beaumont and Sinclair 1996; Kinnie et al. 1999, p. 218; Moule 1998). Large customers may provide small business suppliers with a blueprint for the introduction of HPWPs as part of efforts to ensure that the products and services they supply are delivered to specification (Goss, Adam Smith and Gilbert 1994). However, large or dominant customers are also in a position to exercise market power over their small business suppliers, and they may use this power to drive down prices. This in turn may result in small businesses adopting low cost strategies characterised by authoritarian management, tight supervision and low wages (Rainnie 1989). In such an environment, HPWPs may be viewed as a largely irrelevant and unnecessary expense.

The third market-related factor concerns the workforce skill-mix required to support the product market strategy the business adopts. Businesses pursuing a quality enhancer or innovator strategy, for example, are more likely to require highly skilled employees than are those pursuing a cost reducer or price leadership strategy (Schuler and Jackson 1989). Given this, they will need to provide training in order to maintain skills levels, and design jobs according to HPWP principles (adopting teamworking and multi-skilling, for example) in order to provide employees with opportunities to contribute discretionary effort and ensure they are motivated to do so. Competitive terms and conditions, life-long learning and opportunities for development may also be required given the need to attract and retain highly-skilled employees (Goss 1991). 
The final market-related factor concerns the industry in which the small business operates (Tocher and Rutherford 2009). Variation in the uptake of HPWPs by industry sector might be expected for several reasons. Small businesses in the health and social work sectors, for example, have been found, arguably because of the need for employees' continuing professional development, to be more likely to offer training to their employees than small businesses in the manufacturing sector (Hoque and Bacon 2006). It is also argued that service sector businesses in general may adopt more HPWPs than those in manufacturing given the need to motivate employees to engage in extra-role activities that lead to higher customer satisfaction (Morrison 1996; Schneider et al. 2006). It is quite possible that similar pressures might also exist in small businesses.

\section{Business characteristics}

A number of factors relating to business characteristics might influence the extent of adoption of HPWPs in small businesses. Four such characteristics are considered here: business size; business age; whether the business is single or multi-sited; and the structure of ownership.

Turning first to business size, the returns to HPWPs within small businesses are likely to be affected by relative economies of scale, hence a size threshold may exist above which the benefits from HPWPs begin to exceed their costs. De Grip and Sieben (2009) suggest that HPWPs are unlikely to improve financial performance within micro-businesses (with fewer than ten employees) as they lack the necessary economies of scale to spread the costs of developing and operating such practices. Roberts, Sawbridge and Bamber (1992) propose that small businesses with 20 or more employees will need to introduce formal practices, as beyond this size, informal approaches to management will be inadequate to deal with increasing levels of 
complexity. Hence, one might anticipate variation in the uptake of HPWPs between businesses at the upper and lower ends of the small business size spectrum.

Second, with regard to business age, some empirical studies show that small businesses that have been in operation for several years tend to have more HPWPs in place than those with a short operation history (Faems et al. 2005; Wager 1998). Arguably, this is because the focus of attention within small businesses in their start-up phase will be on staff recruitment rather than on the introduction of HPWPs aimed at employee retention, development and motivation (Hoque and Bacon 2006). However, small businesses are well known for their high failure rates (Robinson, O'Leary and Rincon 2006, pp. 73-74). Given that it may take several years for investments in HPWPs to pay-off, small business managers may only be willing to make such investments once they have become sufficiently confident that the business has a long-term future. As such, a survival effect may make HPWPs more attractive to small businesses the longer they last beyond the initial start-up phase. That said, one might also argue that HPWPs may be more prevalent within new businesses (Ichniowski, Shaw and Prennushi 1997, p. 308) given the possibility that awareness of HPWPs may have increased in recent years among entrepreneurs involved in small business start-ups.

The third structural characteristic that might influence the uptake of HPWPs in small businesses is whether they operate on single or multiple sites. Knocke and Kalleberg (1994) argue that formalised procedures to minimise principal-agent problems are more likely to be necessary in the latter than the former instance. Supporting this, Cully, Woodland, O'Reilly and Dix (1999) found, using data from WERS 1998, that sophisticated employment practices are indeed more prevalent in small workplaces that are part of a larger organisation than in small stand-alone workplaces. 
Finally, the nature of proprietary control might influence the adoption of HPWPs in small businesses. In owner-managed family businesses, lower agency costs may encourage reliance on informal direct management and personal networks based on a sense of mutual obligation (Ram and Edwards 2003) that render HPWPs obsolete. By contrast, non-family owned businesses (and also owner-governed family businesses in which family members are not involved in day-to-day management) need to employ managers from outside the family, and these managers may import into the business the knowledge, skills and experience necessary to introduce HPWPs (Bacon and Hoque 2005). Hence, one might anticipate the uptake of HPWPs to be lower in ownermanaged family businesses than in other small businesses.

\section{Access to expertise}

The final category of factors that might influence the adoption of HPWPs in small businesses concerns their access to HR expertise. One way in which such expertise can be accessed is by hiring a personnel/ HR specialist. Although small businesses are considerably less likely to employ such specialists than are larger businesses (Boxall and Purcell 2008; Cully et al. 1999; Forth et al. 2006) given the lack of economies of scale to justify their presence, one might nevertheless anticipate that in the few instances where they are present, the adoption of HPWPs will be greater. Indeed, previous research has found the presence of personnel/ HR specialists to be positively related to training in small and medium-sized enterprises (SMEs) (Hoque and Bacon 2006). However, Guest and Bryson (2009) found no association between the presence of personnel/ HR specialists and the adoption of innovative HR practices in a representative sample of British workplaces. The association between the presence of such specialists and the adoption of HPWPs in small businesses may similarly be open to question. 
A further route by which small businesses might access HR expertise is via business advisory networks such as employers' associations, local chambers of commerce and Sector Skills Councils. Little research on this issue has been undertaken focusing specifically on small businesses. There has, however, been considerable research exploring the impact of advisory networks on small and medium-sized enterprises (SMEs) as a whole. This research has found that SMEs make greater use of such advice than do large businesses (Forth et al. 2006, p. x), with SME use of external advice on personnel and recruitment issues having more than doubled in the 1990s (Bennett and Robson 2003). This is perhaps unsurprising given the lack of HR expertise within such businesses and the extent to which external advice can reduce the search costs associated with finding solutions to employment-related problems. Advice of this nature has been found to have a significant impact on employment practices in SMEs (ACAS 2002). For example, Erickson and Jacoby (2003) and Hoque and Bacon (2006) find that SMEs that are members of multiple business advisory networks are more likely to train their employees than are non-members of such networks. However, Bennett and Robson (2003) argue that the use of external advice increases once businesses grow beyond the small business size threshold, as business growth requires owner-managers to increase employee training and improve recruitment processes rather than retain their own personal approach to management (Curran and Blackburn 2000, p. 183; Small Business Service 2001, p. 43). The use and influence of business advisory networks on the uptake of HPWPs in small businesses may therefore remain open to question.

Government-sponsored initiatives such as Investors in People (IiP) might provide another source of external expertise for small businesses. IiP offers a best practice blueprint for small businesses to work towards, hence one might expect HPWPs to have been more widely adopted 
in small businesses that have secured IiP recognition (Goss et al. 1994). Against this, however, if small businesses have been compelled to seek IiP (as a requirement from a larger customer, for example), they may view it as a procedural requirement that has no subsequent impact on employment practice once recognition has been secured (Ram 2000). In addition, Gibb (2000) argues that the formalised approach to management encouraged by IiP may not necessarily be appropriate in small businesses. Hence, in instances where they have gained IiP recognition, they may have done so in order to secure its reputational effects rather than because of a desire to implement HPWPs. Supporting this view, Hoque and Bacon $(2006,2008)$ found nonmanagement training to be no higher in IiP than non-IiP small businesses. Given this, it remains open to question whether one would expect liP recognition to be associated with the adoption of HPWPs in small businesses.

Finally, trade unions may provide a further source of expertise on HPWPs for small businesses. Unions are recognised in only 2\% of small business workplaces (Forth et al. 2006, p. 48). Nevertheless, in the workplaces in which they are present, the collective voice/ institutional response model of unionism suggests that unions will voice employee demands for fair treatment and improved terms and conditions (Freeman and Medoff 1984), and managers may respond to this by adopting HPWPs. Additionally, unions might play an 'internal consultant' advisory role (Guest 1995), seeking to improve the terms and conditions of their members by increasing managers' awareness of HPWPs and encouraging their adoption. Supporting this argument, union recognition in small businesses has been found to be associated with higher training levels (Frazis, Herz and Horrigan 1995; Green 1993), and (within SMEs more broadly) with the more widespread adoption of formal induction, discipline and grievance procedures (Bacon and Hoque 
2005). Hence, in the few instances where they are present, unions may be positively associated with the extent of adoption of HPWPs within small businesses.

\section{Data and method of analysis}

The analysis is conducted using data from the WERS 2004 management survey. WERS is designed to be nationally representative of British workplaces with five or more employees within Standard Industrial Classification major groups D to O (agriculture, hunting, forestry and fishing and mining and quarrying are excluded) when probability weighted to account for the complex nature of the WERS survey design. The survey comprises 2,295 observations with a response rate of $64 \%$ (Kersley et al. 2005). Respondents to the survey are the most senior manager in the workplace with responsibility for employee relations matters.

As discussed above, the analysis follows the OECD's (2005, p. 17), the European Commission's (2003) and the U.S. Small Business Administration's (2003) method of defining small businesses as having fewer than 50 employees. Once the public sector and observations with missing data are omitted, this gives a total unweighted subsample of 298 workplaces. The workplaces included within the subsample can either be single-site businesses (whereby the whole business consists of a single workplace) or part of a multi-site business. In the latter instance, it is the size of the business as a whole that is important in determining whether the workplace is in scope. For example, a workplace with 10 employees is only defined as in scope if the organisation to which it belongs has fewer than 50 employees. If the organisation to which it belongs has more than this number of employees, it is excluded from the analysis. Also, given that the WERS question on organisation size asks about the number of employees in the organisation within its UK operations, workplaces that are part of businesses with overseas 
subsidiaries are excluded to ensure the sample does not include businesses with significant numbers of employees outside the UK.

In conducting the analysis, a multivariate approach is adopted within which the dependent variable is a count measure of 17 HPWPs commonly identified as important within previous research (Appelbaum, Bailey, Berg and Kalleberg 2000; Combs et al. 2006; Hoque 2000; Huselid 1995; Wood and de Menezes 1998). Appendix Table 2 presents a full description of the practices and an explanation of how they are constructed. The analysis is conducted using survey Poisson, this being viewed as the standard model where the dependent variable is a count measure (Cameron and Trivedi 1998, p. 9), given the highly non-normal nature of such measures (Greene 1997). Further to this, separate analysis is conducted on each of the 17 individual HPWPs used to construct the count measure, in order to identify the different factors associated with the adoption of each individual practice. Given the dichotomous nature of the 17 individual HPWP variables, survey probit maximum likelihood analysis is used.

\section{INSERT TABLE 1 HERE}

The independent variables used in the analysis are described in Table 1. For the analysis of business size and business age, the sample is restricted to single-site businesses $(n=259)$. For business size, this is because the minimum cut point in the question in WERS concerning the size of the whole organization is 50 employees. Hence, to explore variation by business size in businesses with fewer than this number, restricting the analysis to single site workplaces allows the workplace size measure to be used as a proxy for business size (as in such instances workplace size and business size are one and the same). Where business age is concerned, the 
relevant question in WERS asks about the age of the workplace and not the business. Therefore, restricting the analysis to single site businesses is important as using workplace age as a proxy for business age risks the possibility that some workplaces could be newly-established workplaces of old businesses (hence workplace age could be considerably lower than business age).

The multivariate analysis is weighted throughout by the inverse probability of the selection of the workplace into the sample. This accounts for the stratified nature of the WERS survey design within which certain industry sectors and larger workplaces are disproportionately represented. This is essential if unbiased population estimates are to be achieved.

\section{$\underline{\text { Results }}$}

Factors associated with the HPWP count measure in the small business sector

The analysis of the factors associated with the adoption of the HPWP count variable is reported in Table 2. Where market-related factors are concerned, the results suggest that while a large proportion of small businesses appear to operate in competitive markets (68\%) and have a dominant customer that accounts for more than a quarter of business output (34\%) (Table 1), there is no evidence in Table 2 that either of these factors are associated with the extent of adoption of HPWPs. Workforce skill mix is, however, associated with the greater use of HPWPs, with workplaces in which $75 \%$ or more of the workforce are unskilled having adopted fewer HPWPs than have workplaces in which none of the workforce is unskilled. In relation to industry sector, HPWPs appear to be more prevalent in small businesses in education, health and other community services, and slightly more prevalent (at the $10 \%$ significance level) in transport, finance and other services, than in the manufacturing reference category. They are, however, 
slightly less prevalent (at the $10 \%$ significance level) in wholesale and retail than in manufacturing.

Turning to factors relating to business characteristics, there is no evidence of a size threshold above which HPWPs become particularly prevalent. Where business age is concerned, small businesses that have been in operation for 20 or more years have adopted fewer HPWPs than small businesses that have been in operation for four years or less. Contrary to expectations, HPWPs are less widely adopted in multi-site than in single-site small businesses. Where the nature of proprietary control is concerned, the adoption of HPWPs is higher in owner-governed family businesses (but not non-family owned businesses) than in owner-managed family businesses.

Turning to expertise factors, HPWPs are no more prevalent where a personnel/ HR specialist is present than where a specialist is not present. However, HPWPs are more prevalent in small businesses that are members of business advisory networks than in those that are not members of such networks. HPWPs are also more prevalent in small businesses with IiP recognition than in those without IiP, and they are slightly more prevalent (at the $10 \%$ significance level) in the few small business workplaces that have trade union recognition.

\section{INSERT TABLE 2 HERE}

\section{Factors associated with individual HPWPs within small businesses}

The next stage of the analysis evaluates the antecedents of the 17 individual HPWPs that have been used to construct the HPWP count measure discussed above separately. The analysis, reported in Tables 3 and 4, is restricted to the factors that are significantly associated with the 
count measure of HPWPs in the analysis reported in the previous section. As above, marketrelated factors, factors associated with structural characteristics and factors associated with access to HR expertise are examined in turn.

\section{INSERT TABLE 3 HERE}

i) Market-related factors: With regard to the skill-mix of the workforce, the results in Table 3 suggest that sophisticated recruitment, off-the-job training and performance-related pay are all less prevalent in small businesses in which $75 \%$ or more of the workforce is unskilled than in those where none of the workforce is unskilled. There is also weak evidence (at the $10 \%$ significance level) that internal labour markets, employee attitude surveys and grievance procedures are less prevalent. In addition, none of the businesses in which $75 \%$ or more of the workforce is unskilled have consultation committees, benefits packages or equal opportunities practices as described in Appendix Table 2 in place. Beyond this, several of the HPWPs under observation are more prevalent in small businesses in which none of the workforce is unskilled than in those in which $50-74 \%, 25-49 \%$ or up to $25 \%$ of the workforce is unskilled. The overall pattern within the results, therefore, suggests that the extent of adoption of HPWPs in small businesses is positively related with workforce skill levels.

Where industry sector is concerned, induction, off-the-job training, performance appraisal, employee attitude surveys, quality circles, equal opportunities policies and grievance procedures are all more prevalent in small businesses in the education, health and other community sectors than in small businesses in the manufacturing reference category. Hence, the results confirm the conclusion drawn from the analysis of the count measure with regard to the 
relatively high uptake of HPWPs in small businesses in the education, health and other community sectors. They suggest, however, somewhat inconsistent differences in the adoption of HPWPs between the other non-manufacturing industry sectors and the manufacturing sector. For example, performance appraisal and grievance procedures are more prevalent, and quality circles and equal opportunities policies are slightly more prevalent (at the $10 \%$ significance level) in transport, finance and other services than in manufacturing, while job security policies are slightly less prevalent. Where teamworking is concerned, this is slightly less prevalent (at the $10 \%$ level) in wholesale and retail than in manufacturing. Beyond this, off-the-job training and equal opportunities policies are more prevalent in construction than in manufacturing, whereas internal labour markets, functional flexibility and flexible working/ family friendly practices are slightly less prevalent (at the 10\% level).

ii) Business characteristics: The results for business age in Table 4 suggest that internal labour markets and teamworking are less prevalent in businesses that are 20 years old or older than in businesses that are between 0 and 4 years old. Hence, while the analysis of the HPWP count measure (Table 2) suggests that businesses that are 20 years old or older have adopted fewer HPWPs than have those that are between 0 and 4 years old, this would appear to be driven by a particularly low adoption of just two of the 17 practices under observation. Where the other age categories are concerned, internal labour markets, teamworking, equal opportunities policies and grievance procedures are less prevalent in small businesses that are 10-19 years old than in those that are 0-4 years old, while flexible working/ family friendly practices are more prevalent. Sophisticated recruitment and flexible working/ family friendly practices are more prevalent in small businesses that are 5 to 9 years old than in those that are $0-4$ years old. Overall, therefore, 
the results suggest a somewhat inconsistent pattern in the relationship between the age of the business and the extent of adoption of HPWPs in small businesses.

\section{INSERT TABLE 4 HERE}

Turning to single-site small businesses, Table 3 suggests that sophisticated recruitment, off-the-job training, internal labour markets and flexible working/ family-friendly practices are more prevalent in such businesses than in multi-site small businesses. This confirms the conclusion concerning the higher uptake of HPWPs in single-site than in multi-site small businesses drawn from the analysis of the count measure.

Finally, where proprietary control is concerned, Table 3 suggests that induction, benefits packages and equal opportunities practices are more prevalent in owner-governed family businesses than in owner-managed family businesses. Off-the-job training is also slightly more prevalent (at the 10\% significance level). However, none of the owner-governed family businesses have a consultation committee in place, and employee attitude surveys and job security policies are less prevalent than in owner-managed family businesses. Beyond this, nonfamily owned businesses are more likely than owner-managed family businesses to have adopted a benefits package, but they are less likely to have quality circles. Thus, the analysis does not identify a consistent relationship between proprietary control and the adoption of HPWPs in small businesses.

iii) Access to HR expertise: Table 3 suggests that off-the-job training, performance appraisals, employee attitude surveys and flexible working/family-friendly practices are more 
prevalent, and internal labour markets and quality circles are also slightly more prevalent (at the $10 \%$ significance level) in small businesses that are members of two business advisory networks than in those that are not members of any networks. Businesses that are members of a single network are more likely to have performance appraisals and grievance procedures than are businesses that are not members of any networks. Therefore, membership (particularly multiple memberships) of employer networks would appear to be associated with the likelihood of adoption of a reasonably wide range of HPWPs in small businesses.

Where IiP is concerned, performance-related pay, consultation committees, employee attitude surveys and quality circles are more prevalent in small businesses with IiP than in those without IiP, while off-the-job training, teamworking, equal opportunities policies and grievance procedures are slightly more prevalent (at the $10 \%$ significance level). IiP would appear, therefore, to be associated with the greater uptake of a range of HPWPs in small businesses.

Where union recognition is concerned, consultation committees and grievance procedures (practices one might associate with union recognition) are more prevalent in unionised than nonunionised small businesses, while performance appraisals are slightly less prevalent (at the $10 \%$ level). Hence, while the analysis of the HPWP count measure (in Table 2) suggests that HPWPs are slightly more prevalent in unionised small businesses than in non-union small businesses, this would appear to be driven by a particularly high adoption of just two of the 17 practices under observation.

\section{$\underline{\text { Discussion and Conclusions }}$}

This paper sought to identify the extent to which a range of factors relating to the market in which small businesses operate, their structural characteristics and their access to HR expertise 
are associated with the adoption of HPWPs. In the event, the analysis revealed a number of notable findings.

Turning first to market-related factors, in contrast to previous research, there was no support for the argument that market competition either prevents or stimulates the introduction of HPWPs in the sector (Kinnie et al. 1999). There was also no support for the argument that large or dominant customers influence the likelihood of adoption of HPWPs either by encouraging the adoption of more sophisticated approaches (Gales and Blackburn 1990; Goss et al. 1994; Hendry et al. 1995; Hunter et al. 1996; Kinnie et al. 1999; Moule 1998) or by exerting downward cost pressure on small business suppliers thereby preventing the adoption of HPWPs (Rainnie 1989). One conclusion that might be drawn from this is that small businesses should not be viewed as victims of circumstance whereby market factors such as the degree of competition, their position in the supply chain and subsequent dominance by large business customers dictate the approach they are able to adopt towards managing their employees. As discussed earlier, a large proportion of small businesses operate in competitive markets (68\%) and have a large/ dominant customer (34\%). This does not, however, appear to influence their ability to implement HPWPs. Hence, the findings presented here suggest small businesses may have greater scope to make strategic choices with regard to the management of their employees than is often supposed.

The analysis did however demonstrate a positive relationship between workforce skill mix and the adoption of a wide range of HPWPs, thus supporting the findings of previous research on this issue (Goss 1991; Hoque and Bacon 2006). From a policy perspective, this appears to suggest that small businesses with a highly skilled workforce are likely to be receptive to government efforts to encourage the adoption of HPWPs. However, it could also suggest that governments may find it more difficult to persuade small businesses to adopt HPWPs if they 
have cost reducer or price leadership strategies that do not require a high number of skilled employees.

The analysis also identified differences in the uptake of HPWPs by industry, with HPWPs being particularly prevalent among workplaces in the education, health and other community services sectors. However, HPWPs were found to be only slightly more prevalent in small businesses in transport, finance and other services, no more prevalent in hotels and restaurants, and slightly less prevalent in wholesale and retail than in manufacturing. Hence, the findings provide little support for the argument that service sector businesses are likely to adopt more HPWPs than those in manufacturing because of the need to motivate service workers to engage in extra-role activities that lead to higher customer satisfaction (Morrison 1996; Schneider et al. 2006).

Turning to business characteristics, the analysis did not find the uptake of HPWPs to vary between different-sized small businesses, thus suggesting that if there is a threshold above which HPWPs become particularly prevalent, it is likely to be in excess of the 50 employees size cutpoint for small businesses. The results for business age were somewhat inconsistent, especially where the analysis of individual HPWPs was concerned. Nevertheless, on balance they provided greater support for Ichniowski et al.'s (1997) argument that the adoption of HPWPs will be more widespread in younger than older businesses, rather than the survival effects hypothesis that older small businesses will be more likely to adopt HPWPs (Faems et al. 2005; Wager 1998). In relation to differences between multi and single-site small businesses, the findings did not support the argument that formalised procedures will be particularly prevalent in multi-site businesses (Knocke and Kalleberg 1994). Instead, the results demonstrated the opposite, suggesting that managers may have a greater preference for coordination via HPWPs in single- 
site business. There was also little support for the argument (particularly in the analysis of the adoption of individual HPWPs) that the nature of proprietary control in small businesses has a particular influence on the adoption of HPWPs (Ram and Edwards, 2003).

Turning to small business access to HR expertise, similar to Guest and Bryson's (2009) findings for firms as a whole, the analysis found no relationship between the presence of HR specialists and the adoption of HPWPs in small businesses. The analysis also found little evidence of a union effect. Although union recognition was associated with policies to express employee voice in small businesses (consultation committees and grievance procedures), it was not positively associated with the adoption of any of the other HPWPs.

By contrast, membership of business advisory networks was found to be positively associated with the adoption of a range of HPWPs in small businesses, thus supporting the findings of previous research concerning the influence of such networks (ACAS 2002; Erickson and Jacoby 2003; Hoque and Bacon 2006). The analysis also found a positive relationship between IiP recognition and the adoption of a range of HPWPs. These results may have important implications for government policy. In particular, they suggest that the encouragement of employer engagement with business advisory networks and with IiP could be two key routes by which the government might stimulate the adoption of HPWPs in small businesses. As demonstrated by Table 1, 47\% of small business workplaces are not members of any business advisory networks, and $90 \%$ of small business workplaces within the sample do not have IiP recognition. Should the government be successful in encouraging greater small business engagement with these initiatives, the results here suggest that this could lead to a significant increase in the uptake of HPWPs. 
There are, however, reasons to caution against reaching this conclusion too readily. First, where IiP is concerned, it has been argued elsewhere that in some instances firms will only be interested in seeking IiP recognition either as a marketing tool or for its reputational effects (Ram 2000). If such businesses only introduce HPWPs to secure recognition rather than because of a genuine conviction that such practices will boost performance, it is highly unlikely that the introduction of such practices will be the precursor to higher performance outcomes. Hence, there is a need for caution to ensure that employers are encouraged to seek IiP recognition for the right reasons.

Second, it must be kept in mind that the analysis presented here is based on crosssectional data, hence it is not possible to draw clear causal inferences with regard to the relationship between business advisory networks and IiP recognition and the adoption of HPWPs. Therefore, it is possible that many of the small businesses that engage with business advisory networks and have secured IiP recognition are among those that already had a considerable number of HPWPs in place, hence these initiatives may not have led to an increase in the use of HPWPs per se. This suggests a need for further research to ascertain the extent to which the relationships within these businesses between the adoption of HPWPs and business advisory networks and IiP are causal. Nevertheless, the results presented here suggest, notwithstanding the caveats and the need for further research as highlighted above, that encouraging greater small business engagement with IiP and with business advisory networks could have a potentially important role to play in increasing the adoption of HPWPs within small businesses. 


\section{References}

ACAS (2002), Annual Report 2001-2002, London: ACAS.

Appelbaum, E., Bailey, T., Berg, P., and Kalleberg, A. (2000), Manufacturing Advantage, Ithaca, New York: ILR Press.

Bacon, N., Ackers, P., Storey, J. and Coates, D. (1996), 'It's a Small World: Managing human

Resources in Small Business,' International Journal of Human Resource Management, 7, 82-100.

Bacon, N., and Hoque, K. (2005), 'HRM in the SME sector: valuable employees and coercive networks,' International Journal of Human Resource Management, 16, 1976-1999.

Becker, B. E., and Huselid, M. A. (1998), 'High performance work systems and firm performance: A synthesis of research and managerial implications,' in

Research in personnel and human resource management, ed. G. R. Ferris, Stamford, CT: JAI Press, 16, pp. 53-101.

Bennett, R.J., and. Robson, P.A. (2003), 'Changing Use of External Business Advice and Government Supports by SMEs in the 1990s,' Regional Studies, 37, 795-811.

BIS (2011) Business Populations Estimates for the UK and Regions 2011, Department for Business Innovation and Skills, Statistical Release URN 11/92A.

Boxall, P., and Purcell, J. (2008), Strategy and human resource management (2nd ed.), Hampshire, England: Palgrave-Macmillan.

Cameron, A. C., and Trivedi, P. K. (1998), Regression Analysis of Count Data, Cambridge: Cambridge University Press.

Combs, J., Liu, Y., Hall, A., and Ketchen, D. (2006), 'How much do high-performance work practices matter? A meta-analysis of their effects on organizational performance,' Personnel Psychology, 59, 501-28.

Cully, M., Woodland, S., O'Reilly, A., and Dix, G. (1999), Britain at Work, London: Routledge.

Curran, J., and Blackburn, R.A. (2000), 'Panacea or white elephant? A critical examination of the proposed new small business service and response to the DTI consultancy paper,' Regional Studies, 34, 181-206.

De Grip, A., and Sieben, I. (2009), 'The effectiveness of more advanced human resource systems in small firms,' International Journal of Human Resource Management, 20, 1914-1928.

Department of Trade and Industry (2005), Workplace Employee Relations Survey: CrossSection, 2004 [computer file]. Colchester: The Data Archive [distributor], $22^{\text {nd }}$ December 1999, SN: 5294.

Deshpande, S.P.,and Golhar, D.Y. (1994), 'HRM practices in large and small manufacturing firms: a comparative study,' Journal of Small Business Management, 32, 49-56.

Dundon, T., and Wilkinson, A. (2003), 'Employment Relations in Small Firms', in Handbook of Employment Relations: Law and Practice, ed. B.Towers, (4th ed.), London: Kogan Page.

Edelman, L.F., Brush, C.G., and Manolova, T. (2005), 'Co-alignment in the resource performance relationship: strategy as mediator,' Journal of Business Venturing, 20, 359383.

Erickson, C.L., and Jacoby, S.M. (2003), 'The effect of employer networks on workplace innovation and training,' Industrial and Labor Relations Review, 56, 203-224. 
European Commission (2003), EU SME Definition, 6 May doc C(2003)1422. www.europa.eu.int/comm/enterprise_policy/sme_definition/index_en.htm.

Faems, D., Sels, L., de Winne, S., and Maes, J. (2005), 'The effect of individual HR domains on financial performance: evidence from Belgian small businesses,' International Journal of Human Resource Management, 16, 676-700.

Federation of Small Businesses (2010), Flexible Working: Small Business Solutions, London: Federation of Small Businesses.

Forth, J., Bewley, H., and Bryson, A. (2006), Small and medium-sized enterprises: findings from the 2004 workplace employment relations survey, London: Routledge.

Frazis, H. J., Herz, D. E., and Horrigan, M. W. (1995), 'Employer-provided training: results from a new survey.' Monthly Labor Review, May, 3-17.

Freeman, R., and Medoff, J. (1984), What do unions do?, New York: Basic Books.

Gales, L.M., and Blackburn, R.S. (1990), 'An Analysis of the Impact of Supplier Strategies and Relationships on Small Retailer Actions, Perceptions and Performance,' Entrepreneurship: Theory and Practice, 15, 7-21.

Gibb, A.A. (2000), 'SME policy, academic research and the growth of ignorance, mythical concepts, myths, assumptions, rituals and confusions,' International Small Business Journal, 18, 13-35.

Goss, D., Adam Smith, D., and Gilbert, A. (1994), 'Small firms and HRM: Exceptions that prove the rule?,' Journal of Small Business and Enterprise Development, 1, 2-8.

Goss, D. (1991), 'In search of small firm industrial relations', in Deciphering the Enterprise culture: Entrepreneurship, Petty Capitalism and Restructuring in Britain, ed. R. Burrows, London: Routledge.

Green, F. (1993), 'The impact of trade union membership on training in Britain,' Applied Economics, 25, 1033-1043.

Greene, W.H. (1997) Econometric Analysis ( $3^{\text {rd }}$ ed.), New Jersey: Prentice Hall.

Guest, D., and Bryson, A. (2009), 'From industrial relations to human resource management: the changing role of the personnel function,' in The Evolution of the Modern Workplace, eds. W. Brown, A. Bryson, J. Forth and K. Whitfield, Cambridge: Cambridge University Press, pp. $120-150$.

Guest, D. (1995), 'Human Resource Management: Trade Unions and Industrial Relations,' in Human Resource Management: A Critical Text, ed. J. Storey, London: Routledge.

Hendry, C., Arthur, M.B., and Jones, A.M. (1995), Strategy Through People: Adaptation and Learning in the Small-Medium Enterprise, London: Routledge.

Hoque, K. (2000), Human Resource Management in the Hotel Industry: Strategy, innovation and performance, London: Routledge.

Hoque, K., and Bacon, N. (2006), 'The antecedents of training activity in British small and medium-sized enterprises,' Work, Employment and Society, 20, 531-552.

Hoque, K., and Bacon, N. (2008), 'Investors in People and training in the British SME sector,' Human Relations, 61, 451-482.

Huselid, M. A. (1995), 'The impact of human resource management practices on turnover, productivity, and corporate financial performance,' Academy of Management Journal, 38, 635-672.

Hunter, L., Beaumont, P., and Sinclair, D. (1996), 'A 'partnership' route to human resource management?' Journal of Management Studies, 33, 235-257. 
Ichniowski, C., Shaw, K., and Prennushi, G. (1997), 'The effects of human resource management practices on productivity: a study of steel finishing lines,' American Economic Review, 87, 291-313.

Kersley, B., Alpin, C., Forth, J., Bryson, A., Bewley, H., Dix, G., and Oxenbridge, S. (2005), Inside the workplace: First findings from the 2004 Workplace Employee Relations Survey, London: Department of Trade and Industry.

Kinnie, N., Purcell, J., Hutchinson, S., Terry, M., Collinson, M., and Scarborough, H. (1999), 'Employment relations in SMEs: Market driven or customer-shaped?' Employee Relations, $21,218-235$.

Knocke, D., and Kalleberg, A.L. (1994), 'Job training in U.S. organisations,' American Sociological Review, 59, 537-546.

Messersmith, J.G., and Guthrie, J.M. (2010), 'High performance work systems in emergent organisations: implications for firm performance,' Human Resource Management, 49, 241264.

Morrison EW. (1996), 'Organizational citizenship behavior as a critical link between HRM practices and service quality', Human Resource Management, 35, 493-512.

Moule, C. (1998) Regulation of work in small firms: a view from the inside,' Work, Employment \& Society, 12, 635-653.

OECD (2005), SME and Entrepreneurship Outlook 2005, Paris: Organisation for Economic Cooperation and Development.

Osterman, P. (1994), 'How common is workplace transformation and who adopts it?' Industrial and Labor Relations Review, 47, 173-188.

Rainnie, A. (1989), Industrial Relations in Small Firms, London: Routledge.

Ram, M. (2000), 'Investors in People in small firms: Case study evidence from the business services sector,' Personnel Review, 29, 69-91.

Ram, M., and Edwards, P. (2003), 'Praising Caesar not burying him: what we know about employment relations in small firms,' Work, Employment \& Society, 17, 719-730.

Roberts, I., Sawbridge, D., and Bamber, G. (1992), 'Employee Relations in Smaller Enterprises,' in Handbook of Industrial Relations Practice, ed. B. A. Towers, London: Kogan, pp, 240257.

Robinson, C., O’Leary, B., and Rincon, A. (2006), Business start-ups, closures and economic churn: a review of the literature, National Institute of Economic Research, Final Report for the Small Business Service.

Schneider B, Ehrhart MG, Mayer DM, Saltz JL, Niles-Jolly K. (2006), 'Understanding organizational-customer links in service settings,' Academy of Management Journal,48, $1017-1032$.

Schuler, R. and Jackson, S. (1989), 'Determinants of Human Resource Priorities and Implications for Industrial Relations,' Journal of Management, 15, 89-99.

Sels, L., Winne, S.D., Delmotte, J., Maes, J., Faems, D., and Forrier, A. (2006), 'Linking HRM and small business performance: an examination of the impact of HRM intensity on the productivity and financial performance of small businesses,' Small Business Economics, 26, 83-101.

Small Business Service (2001), Small Firms: Big Business, A Review of Small and Medium Sized Enterprises in the UK, London: HMSO.

Small Business Service (2002), Small Business and Government - The Way Forward, London: HMSO. 
Storey, D. (1994), Understanding the small firm sector, London: Routledge.

US Small Business Administration (2003), How does the SBA define a small business? www.app1.sba.gov/faqs/faqindex.cfm?areaID $=15$.

Tocher, N., and Rutherford, M.W. (2009), 'Perceived acute human resource management problems in small and medium firms: an empirical examination,' Entrepreneurship Theory and Practice, March 455-479.

Wager, T.H. (1998), 'Determinants of human resource management practices in small firms: Some evidence from Atlantic Canada,' Journal of Small Business Management, April 13-23.

Way, S. A. (2002), 'High performance work systems and intermediate indicators of firm performance within the US small business sector,' Journal of Management, 28, 765-785.

Wilkinson, A. (1999), 'Employment relations in SMEs,' Employee Relations, 21, 206-216.

Wood, S., and de Menezes, L. (1998), 'High commitment management in the UK: evidence from the workplace industrial relations survey, and employers' manpower and skills practices survey,' Human Relations, 51, 485-515.

$\mathrm{Wu}$, N., Hoque, K., and Bacon, N. (2011), 'Exploring high performance work systems and performance: the importance of firm size,' Paper presented at BAM HRM SIG, Royal Holloway, Surrey UK. 
Table 1 Factors potentially associated with the adoption of HPWPs in small businesses

Factors

Market-related factors

Highly competitive market

Largest customer

Largest customer accountable for $\leq 25 \%$ of output

Largest customer accountable for $\geq 26 \%$ of output

Skill-mix

No unskilled employees

$>0-24 \%$ unskilled

25-49\% unskilled

50-74\% unskilled

$75 \%+$ unskilled

Industry sectors

Manufacturing

Construction

Wholesale and retail

Hotels and restaurants

Transport, finance and other services

Education, health and other community services

$\underline{\text { Structural characteristics }}$

Business size ${ }^{l}$

5-9 employees

10-19 employees

35.5

20-34 employees

35-49 employees

Business age ${ }^{I}$

0-4 years old

5-9 years old

16.5

10-19 years old

24.8

$20+$ years old

Single-site business ${ }^{1}$

Family ownership

Owner-managed family business

Owner-governed family business

Non-family owned business

\section{Access to HR expertise}

Personnel/HR specialist

Business advisory network ${ }^{2}$

Not a member of any business advisory networks

Member of 1 network

Member of 2 networks

IiP recognition

Union recognition

Notes: All percentages are weighted. N=298.

${ }^{1}$ Analysis restricted to single-site businesses ( $\left.\mathrm{N}=259\right)$.

${ }^{2}$ The business advisory networks under consideration are: employers'/trade associations, chamber of commerce, Federation of Small Businesses and some other similar group. No small workplaces in the sample are members of more than two. 
Table 2 Factors associated with the uptake of HPWPs in small businesses

\begin{tabular}{|c|c|c|c|c|}
\hline & Model 1 & & & Model $2^{1}$ \\
\hline \multicolumn{5}{|l|}{ Market-related factors } \\
\hline Highly competitive market & 0.080 & $(0.082)$ & & \\
\hline \multicolumn{5}{|c|}{ Reference category: Largest customer accountable for $\leq 25 \%$ of output } \\
\hline Largest customer accountable for $\geq 26 \%$ of output & -0.146 & $(0.090)$ & & \\
\hline \multicolumn{5}{|l|}{ Reference category: No unskilled employees } \\
\hline$>0-24 \%$ unskilled & 0.008 & $(0.101)$ & & \\
\hline $25-49 \%$ unskilled & -0.355 & $(0.180)^{*}$ & & \\
\hline 50-74\% unskilled & -0.034 & $(0.205)$ & & \\
\hline $75 \%+$ unskilled & -0.541 & $(0.191)^{* * *}$ & & \\
\hline \multicolumn{5}{|l|}{ Reference category: Manufacturing } \\
\hline Construction & 0.103 & $(0.171)$ & & \\
\hline Wholesale and retail & -0.315 & $(0.173)^{*}$ & & \\
\hline Hotels and restaurants & -0.235 & $(0.231)$ & & \\
\hline Transport, finance and other services & 0.300 & $(0.155)^{*}$ & & \\
\hline Education, health and other community services & 0.516 & $(0.152)^{* * *}$ & & \\
\hline \multicolumn{5}{|l|}{$\underline{\text { Structural characteristics }}$} \\
\hline \multicolumn{5}{|l|}{ Reference category: Small business: 5-9 employees } \\
\hline 10-19 employees & & & -0.031 & $(0.097)$ \\
\hline 20-34 employees & & & -0.184 & $(0.118)$ \\
\hline 35-49 employees & & & 0.129 & $(0.142)$ \\
\hline \multicolumn{5}{|l|}{ Reference category: Small business: 0-4 years old } \\
\hline $5-9$ years old & & & 0.186 & $(0.135)$ \\
\hline 10-19 years old & & & -0.126 & $(0.140)$ \\
\hline $20+$ years old & & & -0.274 & $(0.131)^{* *}$ \\
\hline Single-site business & 0.277 & $(0.120)^{* *}$ & & \\
\hline \multicolumn{5}{|l|}{ Reference category: Owner-managed family business } \\
\hline Owner-governed family business & 0.294 & $(0.115)^{* *}$ & & \\
\hline Non-family owned business & 0.018 & $(0.090)$ & & \\
\hline \multicolumn{5}{|l|}{ Access to HR expertise } \\
\hline Personnel/HR specialist & -0.030 & $(0.126)$ & & \\
\hline \multicolumn{5}{|c|}{ Reference category: Not a member of any business advisory networks } \\
\hline Member of 1 network & 0.191 & $(0.084)^{* *}$ & & \\
\hline Member of 2 networks & 0.369 & $(0.123)^{* * *}$ & & \\
\hline IiP recognition & 0.362 & $(0.093)^{* * *}$ & & \\
\hline Union recognition & 0.310 & $(0.173)^{*}$ & & \\
\hline $\mathrm{N}$ & 11.19 & & 9.32 & \\
\hline $\mathrm{F}$ & 0.000 & & 0.000 & \\
\hline Prob $>$ F & 298 & & 259 & \\
\hline
\end{tabular}

Notes: Survey Poisson analysis.

All estimations are weighted. Coefficients given (standard errors in brackets).

${ }^{1}$ All variables in Model 1 are included in Model 2 except for 'single-site businesses'. Only the coefficients for business size and business age are reported here.

$* * *$ significant at $1 \% * *$ significant at $5 \% *$ significant at $10 \%$. 
Table 3 Factors $^{1}$ associated with individual HPWPs in small businesses

\begin{tabular}{|c|c|c|c|c|c|c|c|c|}
\hline & Sophisticated recruitme & Induction & Off-the-job training & $\begin{array}{l}\text { Internal labour } \\
\text { market }\end{array}$ & $\begin{array}{l}\text { Performance-related } \\
\text { pay }\end{array}$ & $\begin{array}{l}\text { Performance } \\
\text { appraisal }\end{array}$ & Teamworking & Team briefing \\
\hline \multicolumn{9}{|l|}{ Market-related factors } \\
\hline \multicolumn{9}{|c|}{ Skill-mix: Ref. category: No unskilled employees } \\
\hline$>0-24 \%$ unskilled & $0.338(0.249)$ & $-0.298(0.234)$ & $0.386(0.248)$ & $-0.314(0.284)$ & $-0.416(0.247)^{*}$ & $0.008(0.255)$ & $0.008(0.228)$ & $-0.231(0.262)$ \\
\hline $25-49 \%$ unskilled & $-0.187(0.397)$ & $-0.591(0.399)$ & $-0.682(0.388)^{*}$ & $-0.036(0.440)$ & $-0.908(0.388)^{* *}$ & $-0.623(0.435)$ & $-0.161(0.427)$ & $-0.114(0.387)$ \\
\hline $50-74 \%$ unskilled & $-0.421(0.402)$ & $-0.476(0.424)$ & $-0.167(0.399)$ & $-0.910(0.580)$ & $-0.319(0.520)$ & $-0.385(0.451)$ & $0.598(0.427)$ & $0.564(0.519)$ \\
\hline $75 \%+$ unskilled & $-0.827(0.342)^{* *}$ & $-0.471(0.358)$ & $-0.810(0.350)^{* *}$ & $-0.779(0.406)^{*}$ & $-0.959(0.354)^{* * * *}$ & $-0.280(0.509)$ & $0.314(0.400)$ & $-0.540(0.412)$ \\
\hline \multicolumn{9}{|l|}{$\begin{array}{l}\text { Industry sector: Ref. category: } \\
\text { Manufacturing }\end{array}$} \\
\hline Construction & $-0.073(0.439)$ & $-0.010(0.432)$ & $0.910(0.429)^{* *}$ & $-0.863(0.446)^{*}$ & $-0.160(0.427)$ & $0.643(0.416)$ & $0.482(0.409)$ & $0.509(0.414)$ \\
\hline Wholesale and retail & $-0.378(0.373)$ & $0.199(0.333)$ & $-0.458(0.372)$ & $-0.251(0.368)$ & $0.169(0.379)$ & $-0.319(0.359)$ & $-0.599(0.346)^{*}$ & $-0.299(0.381)$ \\
\hline Hotels and restaurants & $-0.145(0.420)$ & $0.002(0.420)$ & $-0.403(0.484)$ & $-0.038(0.456)$ & $-0.518(0.520)$ & $0.685(0.548)$ & $-0.556(0.461)$ & $0.085(0.483)$ \\
\hline Transport, finance and other services & $0.404(0.327)$ & $0.407(0.303)$ & $0.594(0.358)$ & $-0.107(0.339)$ & $0.339(0.372)$ & $0.822(0.314)^{* * *}$ & $0.119(0.319)$ & $0.440(0.337)$ \\
\hline Education, health and other community & $0.254(0.332)$ & $0.835(0.307)^{* * *}$ & $0.811(0.354)^{* *}$ & $-0.418(0.335)$ & $-0.033(0.393)$ & $1.534(0.331)^{* * *}$ & $0.377(0.331)$ & $0.381(0.343)$ \\
\hline \multicolumn{9}{|l|}{$\underline{\text { Structural characteristics }}$} \\
\hline Single-site business & $0.603(0.284)^{* *}$ & $0.369(0.277)$ & $0.726(0.321)^{* *}$ & $0.692(0.305)^{* *}$ & $0.138(0.299)$ & $0.370(0.264)$ & $-0.239(0.257)$ & $-0.246(0.287)$ \\
\hline \multicolumn{9}{|c|}{ Family ownership: Ref. category: Owner-managed family business } \\
\hline Owner-governed family business & $0.260(0.376)$ & $1.041(0.330)^{* * *}$ & $0.664(0.370)^{*}$ & $0.093(0.341)$ & $0.456(0.365)$ & $0.251(0.334)$ & $0.491(0.353)$ & $-0.069(0.327)$ \\
\hline Non-family owned business & $0.087(0.212)$ & $-0.152(0.201)$ & $0.220(0.243)$ & $-0.136(0.222)$ & $0.031(0.249)$ & $0.011(0.225)$ & $0.186(0.209)$ & $-0.216(0.221)$ \\
\hline \multicolumn{9}{|l|}{ Access to HR expertise } \\
\hline \multicolumn{9}{|c|}{ Business advisory network: Ref. category: Not a member of any networks } \\
\hline Member of 1 network & $0.222(0.212)$ & $-0.102(0.203)$ & $0.136(0.215)$ & $0.191(0.238)$ & $-0.192(0.230)$ & $0.547(0.207)^{* * *}$ & $0.137(0.197)$ & $0.490(0.214)$ \\
\hline Member of 2 networks & $0.151(0.272)$ & $0.114(0.282)$ & $0.830(0.279)^{* * * *}$ & $0.523(0.292)^{*}$ & $-0.020(0.309)$ & $0.922(0.290)^{* * *}$ & $-0.166(0.266)$ & $0.491(0.309)$ \\
\hline IiP recognition & $0.293(0.279)$ & $-0.041(0.298)$ & $0.576(0.322)^{*}$ & $0.318(0.288)$ & $0.792(0.297)^{* * *}$ & $0.255(0.314)$ & $0.552(0.296)^{*}$ & $-0.213(0.297)$ \\
\hline Union recognition & $-0.053(0.373)$ & $0.471(0.424)$ & $0.397(0.425)$ & $0.312(0.430)$ & $-0.257(0.506)$ & $-0.687(0.389)^{*}$ & $0.255(0.401)$ & $-0.118(0.378)$ \\
\hline $\mathrm{N}$ & 298 & 298 & 298 & 298 & 298 & 298 & 298 & 298 \\
\hline $\mathrm{F}$ & 1.57 & 1.94 & 3.59 & 1.26 & 2.21 & 3.66 & 1.77 & 1.02 \\
\hline Prob $>$ F & 0.077 & 0.017 & 0.000 & 0.225 & 0.005 & 0.000 & 0.035 & 0.432 \\
\hline
\end{tabular}




\begin{tabular}{|c|c|c|c|c|c|c|c|c|c|}
\hline (Cont.) & $\begin{array}{l}\text { Consultation } \\
\text { committee }\end{array}$ & $\begin{array}{l}\text { Employee attitude } \\
\text { survey }\end{array}$ & Quality circles & $\begin{array}{l}\text { Functional } \\
\text { flexibility }\end{array}$ & Benefits package & $\begin{array}{c}\text { Flexible } \\
\text { working/family } \\
\text { friendly }\end{array}$ & $\begin{array}{l}\text { Equal opportunities } \\
\text { practices }\end{array}$ & $\begin{array}{l}\text { Grievance } \\
\text { procedures }\end{array}$ & Job security \\
\hline \multicolumn{10}{|l|}{$\underline{\text { Market-related factors }}$} \\
\hline \multicolumn{10}{|c|}{ Skill-mix: Ref. category: No unskilled employees } \\
\hline$>0-24 \%$ unskilled & $0.346(0.363)$ & $0.301(0.258)$ & $0.163(0.253)$ & $0.402(0.261)$ & $-0.043(0.278)$ & $-0.499(0.280)^{*}$ & $-0.894(0.466)^{*}$ & (f) & $0.031(0.313)$ \\
\hline $25-49 \%$ unskilled & $0.415(0.477)$ & $-0.434(0.342)$ & $-1.027(0.556)^{*}$ & $0.809(0.394)^{* *}$ & $-1.290(0.495)^{* * *}$ & $-0.757(0.464)$ & $0.225(0.453)$ & $-0.026(0.243)$ & $0.266(0.445)$ \\
\hline $50-74 \%$ unskilled & $-0.458(0.587)$ & $0.216(0.562)$ & $-0.772(0.390)^{* *}$ & $0.458(0.525)$ & (e) & $-0.198(0.553)$ & $-0.125(0.464)$ & $-0.184(0.408)$ & $-0.053(0.575)$ \\
\hline $75 \%+$ unskilled & (a) & $-1.005(0.570)^{*}$ & $-0.956(0.651)$ & $-0.568(0.423)$ & & $-0.273(0.605)$ & (a) & $-0.663(0.350)^{*}$ & $1.000(0.565)^{*}$ \\
\hline \multicolumn{10}{|l|}{$\begin{array}{l}\text { Industry sector: Ref. category: } \\
\text { Manufacturing }\end{array}$} \\
\hline Construction & $-0.002(0.455)$ & $-0.251(0.420)$ & $-0.458(0.432)$ & $-0.791(0.435)^{*}$ & $-0.480(0.376)$ & $-0.829(0.441)^{*}$ & $1.462(0.544)^{* * *}$ & $0.302(0.460)$ & $0.535(0.452)$ \\
\hline Wholesale and retail & (b) & $-0.165(0.394)$ & $0.116(0.400)$ & $-0.082(0.348)$ & (d) & $-0.179(0.405)$ & $0.156(0.593)$ & $0.094(0.403)$ & $-0.532(0.436)$ \\
\hline Hotels and restaurants & & $0.033(0.644)$ & $-0.300(0.458)$ & $-0.107(0.463)$ & & $-0.462(0.608)$ & $0.202(0.666)$ & $0.355(0.411)$ & $-0.460(0.656)$ \\
\hline Transport, finance and other services & $-0.056(0.502)$ & $0.263(0.320)$ & $0.641(0.328)^{*}$ & $-0.316(0.325)$ & $0.005(0.308)$ & $0.059(0.360)$ & $0.997(0.510)^{*}$ & $0.703(0.317)^{* *}$ & $-0.913(0.505)^{*}$ \\
\hline Education, health and other community & $0.495(0.432)$ & $0.695(0.315)^{* *}$ & $1.019(0.344)^{* * *}$ & $-0.367(0.316)$ & $-0.205(0.337)$ & $0.207(0.349)$ & $1.575(0.448)^{* * *}$ & $0.849(0.311)^{* * *}$ & $0.468(0.420)$ \\
\hline \multicolumn{10}{|l|}{$\underline{\text { Structural characteristics }}$} \\
\hline Single-site business & $-0.585(0.391)$ & $0.554(0.389)$ & $-0.161(0.291)$ & $0.382(0.319)$ & $0.438(0.328)$ & $0.743(0.358)^{* *}$ & $-0.405(0.343)$ & $-0.120(0.255)$ & $0.240(0.388)$ \\
\hline \multicolumn{10}{|c|}{ Family ownership: Ref. category: Owner-managed family business } \\
\hline Owner-governed family business & (c) & $-0.666(0.337)^{* *}$ & $0.125(0.408)$ & $-0.590(0.475)$ & $1.010(0.399)^{* *}$ & $0.527(0.382)$ & $0.877(0.386)^{* *}$ & $-0.054(0.338)$ & $-1.055(0.513)^{* *}$ \\
\hline Non-family owned business & $-0.054(0.307)$ & $-0.320(0.221)$ & $-0.648(0.241)^{* * *}$ & $0.269(0.238)$ & $0.455(0.216)^{* *}$ & $0.019(0.253)$ & $0.075(0.281)$ & $-0.132(0.203)$ & $-0.150(0.316)$ \\
\hline \multicolumn{10}{|l|}{ Access to HR expertise } \\
\hline \multicolumn{10}{|c|}{ Business advisory network: Ref. category: Not a member of any networks } \\
\hline Member of 1 network & $0.299(0.325)$ & $-0.116(0.230)$ & $0.007(0.245)$ & $0.081(0.224)$ & $-0.042(0.238)$ & $0.317(0.238)$ & $-0.200(0.266)$ & $0.437(0.204)^{* *}$ & $0.382(0.263)$ \\
\hline Member of 2 networks & $0.031(0.425)$ & $0.685(0.295)^{* *}$ & $0.620(0.327)^{*}$ & $0.305(0.307)$ & $0.178(0.272)$ & $0.689(0.326)^{* *}$ & $0.235(0.357)$ & $-0.037(0.288)$ & $-0.214(0.350)$ \\
\hline IiP recognition & $1.253(0.401)^{* * *}$ & $1.031(0.310)^{* * *}$ & $0.734(0.334)^{* *}$ & $-0.126(0.364)$ & $-0.191(0.314)$ & $0.439(0.325)$ & $0.568(0.310)^{*}$ & $0.484(0.276)^{*}$ & $-0.351(0.444)$ \\
\hline Union recognition & $1.710(0.474)^{* * *}$ & $0.171(0.398)$ & $0.636(0.400)$ & $-0.095(0.482)$ & $0.551(0.400)$ & $0.548(0.391)$ & $0.696(0.458)$ & $0.955(0.417)^{* *}$ & $-0.203(0.482)$ \\
\hline $\mathrm{N}$ & 298 & 298 & 298 & 298 & 298 & 298 & 298 & 298 & 298 \\
\hline $\mathrm{F}$ & 3.2 & 2.5 & 3.96 & 1.14 & 2.03 & 2.24 & 3.01 & 2.11 & 1.97 \\
\hline Prob $>$ F & 0.000 & 0.001 & 0.000 & 0.320 & 0.014 & 0.005 & 0.000 & 0.010 & 0.015 \\
\hline
\end{tabular}

Notes: Survey probit analysis. Coefficients given (standard errors in brackets). $* * *$ significant at $1 \% * *$ significant at $5 \% *$ significant at $10 \%$

${ }^{1}$ Only variables that demonstrate significant associations with any of the factors described in Model 1 (see in Table 2) are reported here.

(a) Two skill-mix categories ('50-74\% unskilled' and ' $75 \%+$ unskilled') are combined as none of the workplaces in the latter have a consultation committee/ equal opportunity practices.

(b) 'Construction', 'Hotels and restaurants' and 'Wholesale and retail' are combined as none of the workplaces in the first two categories have a consultation committee.

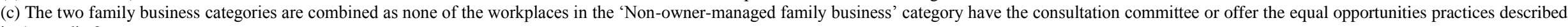
in Appendix 2.

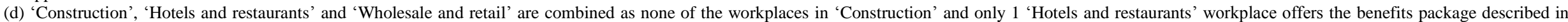
Appendix 2

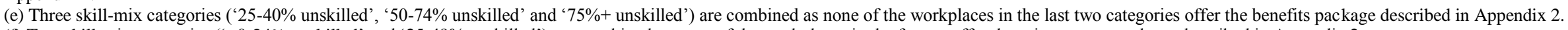

(f) Two skill-mix categories ('>0-24\% unskilled' and ' $25-49 \%$ unskilled') are combined as none of the workplaces in the former offer the grievance procedures described in Appendix 2 . 
Table 4 The association between single-site businesses and individual HPWPs ${ }^{1}$ in small businesses

\begin{tabular}{|c|c|c|c|c|c|c|}
\hline & \multicolumn{2}{|c|}{ Sophisticated recruitment } & \multicolumn{2}{|c|}{ Internal labour market } & \multicolumn{2}{|c|}{ Teamworking } \\
\hline \multicolumn{7}{|c|}{ Business age: Ref. category $=0-4$ years old } \\
\hline $5-9$ years old & 1.067 & $(0.369)^{* * *}$ & -0.408 & $(0.386)$ & -0.364 & $(0.356)$ \\
\hline $10-19$ years old & 0.511 & $(0.365)$ & -0.942 & $(0.375)^{* *}$ & -0.719 & $(0.318)^{* *}$ \\
\hline $20+$ years old & 0.404 & $(0.346)$ & -1.074 & $(0.384)^{* * *}$ & -0.792 & $(0.313)^{* *}$ \\
\hline $\mathrm{N}$ & 259 & & 259 & & 259 & \\
\hline $\mathrm{F}$ & 1.83 & & 1.74 & & 1.84 & \\
\hline Prob $>$ F & 0.013 & & 0.020 & & 0.012 & \\
\hline
\end{tabular}

Flexible working/family friendly

Equal opportunities practices

$-0.141 \quad(0.353)$

$-0.951(0.371)^{* *}$

$-0.517 \quad(0.378)$

$0.488 \quad(0.418)$

259

2.16

0.002

Prob $>$ F

Notes: Survey probit analysis. Coefficients given (standard errors in brackets).

All equations include variables used in Model 2 in Table 2.

${ }^{1}$ Only HPWPs that demonstrate significant associations with single-site businesses are reported here.

$* * *$ significant at $1 \% * *$ significant at $5 \% *$ significant at $10 \%$.

\begin{tabular}{lrlrr} 
5-9 years old & 1.245 & $(0.459)^{* * *}$ & -0.141 & $(0.353)$ \\
10-19 years old & 0.876 & $(0.415)^{* *}$ & -0.951 & $(0.371)$ \\
20+ years old & 0.488 & $(0.418)$ & -0.517 & $(0.378)$ \\
$\mathrm{N}$ & 259 & & 259 \\
$\mathrm{~F}$ & 2.16 & 3.06 \\
Prob > F & 0.002 & 0.000 \\
\hline Notes: Survey probit analysis. Coefficients given (standard errors in brackets). & \\
All equations include variables used in Model 2 in Table 2. & \\
19nly HPWPs that demonstrate significant associations with single-site businesses are reported here. \\
*** significant at 1\% ** significant at 5\% $*$ significant at 10\%.
\end{tabular}

Grievance procedures

$\begin{aligned}-0.114 & (0.353) \\ -0.710 & (0.332)^{* *} \\ -0.295 & (0.301) \\ 259 & \\ 2.39 & \\ 0.001 & \end{aligned}$

$\begin{array}{ll}-0.364 & (0.356)\end{array}$ 


\section{$\underline{\text { HPWPs }}$}

Sophisticated recruitment

Off-the-job training

Internal labour market

Performance-related pay

Performance appraisal

Teamworking

Team briefing

Consultation committee

Employee attitude survey

Quality circles

Functional flexibility

Benefits package

Family-friendly/flexible working

Equal opportunities practices

Grievance procedures

Notes: All means are weighted.

$\mathrm{N}=298$ 


HPWPs

Sophisticated recruitment

Induction

Off-the-job training

Internal labour market

Performance-related pay

Performance appraisal

Teamworking

Team briefing

Consultation committee

Employee attitude survey

Quality circles

Functional flexibility

Benefits package

Flexible working/family-friendly practices

Equal opportunities practices

Grievance procedures
Items

Either a personality/attitude test or performance/competency test is conducted in filling largest occupational group (LOG) vacancies.

A standard induction programme designed to introduce new non-managerial employees belonging to the LOG to the workplace and such induction activities normally last for at least 2 days (if counted in days) or at least 16 hours (if counted in hours).

At least $60 \%$ of experienced workers in the LOG have been given time off from their normal daily work duties to undertake training over the past 12 months.

Preference is given to internal applicants, other things being equal, over external applicants; or internal applicants are the only source when filling vacancies.

At least $60 \%$ of non-managerial employees at the workplace are paid according to results or receive merit pay.

At least $60 \%$ of non-managerial employees at the workplace have their performance appraised at least annually.

At least $60 \%$ of the LOG at the workplace are working in formally designated teams.

Meetings held at least weekly between line managers or supervisors and all the workers for whom they are responsible.

Committees of managers and employees at the workplace, primarily concerned with consultation rather than negotiation (joint consultative committees, works councils or representative forums).

Employer or a third party has conducted a formal survey of employees' views or opinions during the past two years and the results of the survey have been made available in written form to employees that took part.

At least $60 \%$ of the LOG at the workplace have been involved in problem-solving groups, quality circles or continuous improvement groups.

At least $60 \%$ of the LOG are formally trained to do jobs other than their own.

Three or more of the following non-pay terms and conditions apply to the LOG: employer pension scheme, private health insurance, more than four weeks of paid annual leave (excluding public holidays), sick pay in excess of statutory requirements.

Three or more of the following are practised at the workplace: working at or from home in normal working hours; job sharing schemes; flexitime where an employee has no set start or finish time but there is an agreement to work a set number of hours per week or per month; any female employees going on maternity leave receive their normal full rate of pay; working only during school term-time; workplace nursery or nursery linked with workplace; financial help with child-care; financial help with the care of older adults; a specific period of leave for carers of older adults.

Recruitment and selection have been monitored or reviewed to identify indirect discrimination by at least three of gender, ethnic background, disability and age; or promotion procedures have been monitored or reviewed to identify indirect discrimination by at least three of gender, ethnic background, disability and age.

Workplaces that have all of the following four items are deemed as having a formal grievance procedure: a formal procedure for dealing with individual grievances raised by any employee at the workplace; employees are required to set out in writing the nature of the grievance; employees are asked to attend a formal meeting with a manager to discuss the nature of their grievance; and employees have a right to appeal against a decision made under the procedure.

Job security or no-compulsory redundancy policy applies to the LOG. 